\title{
Daily, seasonal, and annual variability of temperature in streams inhabited by the endemic San Pedro Martir trout (Oncorhynchus mykiss nelsoni), in Baja California, Mexico, and the predicted temperature for the years 2025 and 2050
}

\author{
Iván A. Meza-Matty, ${ }^{1,2}$ Gorgonio Ruiz-Campos, ${ }^{2 *}$ Luis Walter Daesslé, ${ }^{1}$ Arturo Ruiz-Luna, ${ }^{3}$ \\ Álvaro Alberto López-Lambraño, ${ }^{4}$ Faustino Camarena-Rosales, ${ }^{2}$ Kathleen R. Matthews ${ }^{5}$ \\ ${ }^{1}$ Instituto de Investigaciones Oceanológicas, Universidad Autónoma de Baja California, Carretera Tijuana-Ensenada No. 3917, \\ Fraccionamiento Playitas, CP 22860 Ensenada, Baja California, Mexico; ${ }^{2}$ Facultad de Ciencias, Universidad Autónoma de Baja \\ California. Carretera Transpeninsular Tijuana-Ensenada No. 3917, Fraccionamiento Playitas, CP 22860 Ensenada, Baja California, \\ Mexico; ${ }^{3}$ Centro de Investigación en Alimentación y Desarrollo, Unidad Académica Mazatlán en Acuicultura y Manejo Ambiental. \\ Avenida Sábalo Cerritos s/n, CP 82112 Mazatlán, Sinaloa, Mexico; ${ }^{4}$ Facultad de Ingeniería, Arquitectura y Diseño, Carretera \\ Transpeninsular Tijuana-Ensenada No. 3917, Fraccionamiento Playitas, CP 22860 Ensenada, Baja California, Mexico; ${ }^{5}$ U.S. Department \\ of Agriculture, Forest Service, Pacific Southwest Research Station, 800 Buchanan St, Albany, CA 94710, USA (Retired)
}

\begin{abstract}
The present study measured the daily, seasonal, and annual variability of the water temperature of streams in which the endemic rainbow trout, Oncorhynchus mykiss nelsoni, is distributed on the western slope of the Sierra San Pedro Mártir, Baja California, Mexico, between 1996 and 2019. The seasonal thermal interval and daily duration of summer temperatures above the thermal threshold for this trout subspecies $\left(\geq 28^{\circ} \mathrm{C}\right)$ were determined in streams at different elevations $(553,1,220$, and 2,080 m asl, or meters above sea level). Temperatures $28^{\circ} \mathrm{C}$ were recorded at the study site on the stream with the lowest elevation (San Antonio de Murillos Creek) over an accumulated $365 \mathrm{~h}$ between June and September 2014, with the maximum temperature recorded there, $30.66{ }^{\circ} \mathrm{C}$, making it the site most vulnerable to global warming. At the San Antonio de Murillos Creek site, the average water temperature predicted by three models (GFDL R30, HadCM3, and Mote) for the year 2025 would be a non-lethal temperature, $<28^{\circ} \mathrm{C}$, for trout at a minimum elevation of 491-511 masl, while this was predicted to be 545-701 masl for the year 2050 . Predicted hourly water temperatures of $28^{\circ} \mathrm{C}$ (non-lethal) may occur at minimum elevations of 868-898 masl in 2025 and at 908-1028 masl in 2050, reducing a 21-23\% and 23-31\% its current altitudinal distribution range, respectively, thus avoiding its presence at the type locality (San Antonio de Murillos).
\end{abstract}

\section{INTRODUCTION}

Global warming affects the distribution of species and modifies their habitat by increasing or decreasing their range of distribution (Parmesan and Yohe, 2003; Root et al., 2003). The Intergovernmental Panel on Climate Change (IPCC) (2007) states that the global warming evident in the recent instrumental record will continue and even acceler-

Corresponding author: gruiz@uabc.edu.mx

Keywords: Oncorhynchus mykiss nelsoni; global warming; water temperature; endemic; creek; model.

Edited by: Franco Tassi, Department of Earth Sciences, University of Florence, Italy.

Received: 28 December 2020

Accepted: 15 April 2021

This work is licensed under a Creative Commons Attribution NonCommercial 4.0 License (CC BY-NC 4.0).

${ }^{\circ}$ Copyright: the Author(s), 2021

Licensee PAGEPress, Italy

J. Limnol., 2021; 80(2):2001

DOI: 10.4081/jlimnol.2021.2001 ate. Global temperatures have increased by an average of approximately $0.85^{\circ} \mathrm{C}$ since the end of the $19^{\text {th }}$ century, and extreme climatic events, including storms, floods, droughts, and heatwaves, are increasing in frequency (Christensen and Christensen, 2003; Stocker et al., 2013).

Warmer air temperatures (Abatzoglou and Redmond, 2007; IPCC, 2007) cause an increase in the variability of rainfall (Hamlet et al., 2007) and the frequency of forest fires (Westerling et al., 2006; Morgan et al., 2008), as well as decreased snow cover and dissolved oxygen levels of water (Mote et al., 2005). The events before mentioned are responsible of the warming of river and stream waters (Petersen and Kitchell, 2001; Morrison et al., 2002; Bartholow, 2005), the alteration of hydrological currents (Barnett et al., 2008; Luce and Holden, 2009), and the increased disturbance of river beds due to flooding, landslides, and debris flow (Istanbulluoglu et al., 2004; Hamlet and Lettenmaier, 2007).

Temperature largely governs the distribution and abundance of species on a spatial and temporal scale (Rieman et al., 2007; Wenger et al., 2011). As global warming progresses and the planet's temperatures rise, aquatic communities in lotic systems such as streams and rivers will have to adapt to new thermally-modified habitats. However, these communities can undergo adaptation difficulties in places where river networks are fragmented due to the development of water infrastructure that modify 
the quality and quantity of flow downstream (Daufresne and Boet, 2007; Heino et al., 2009). The members of the family Salmonidae are strictly dependent on cold waters with high levels of oxygenation and flow (Leppi et al., 2010), so changes in maximum water temperatures of only a few degrees due to global warming can have significant effects on the occurrence and distribution of trout in streams (Magnuson et al., 1997; Lyons et al., 2009; Rieman and Isaak, 2010).

It is well-known that water temperatures $>25^{\circ} \mathrm{C}$ result to be lethal for most rainbow trout (Bidgood and Berst, 1969), including the southern rainbow trout subspecies (Matthews, 2010). The streams of southern California, USA, register temperatures as high as $28^{\circ} \mathrm{C}$ in the summer, with rainbow trout preferring the habitat of cold deep pools to the warmer conditions in streams (Matthews and Berg, 1997). One possible explanation for the survival of this trout in high temperatures is the refuge offered by the thermal micro-shelters created by groundwater inlets or stratified ponds (Matthews and Berg, 1997). However, the extent of the refuge habitat offered by these sites is uncertain due to the likely increase in water temperature in the coming decades.

Various factors influence the habitat suitability of salmonid fishes. Crozier and Zabel (2006) found a low survival of salmonids in warm wide streams with low flow rates, while a high survival in colder narrower streams with flow rates. In warmer, wider streams, the individual's developmental process deteriorates as the temperature rises above the optimal level, while the risk of predation increases (Marine and Cech, 2004) and the availability of prey decreases (Bisson and Davis, 1976).

The endemic trout O. m. nelsoni (Evermann, 1908) inhabits the western slope of the Sierra San Pedro Mártir (SSPM), northwestern Baja California, Mexico and is considered as the southernmost subspecies of the rainbow complex in North America (Behnke, 2002). This trout is in the category of special protection (Ruiz-Campos and Pister, 1995; Official Mexican Standard, 2010; Ruiz-Campos et al., 2014) and face a series of threats related to the alteration of their habitats due to the impact of cattle farming and the reduction of stream flow as result of pumping or channeling water for agricultural irrigation in the adjacent coastal region (Ruiz-Campos, 2017). Therefore, there is the imminent threat of reduction in its distribution by global warming's predicted increased water temperature. The trout would only survive in higher elevations conducive to the formation of thermal micro-shelters (Rieman and Isaak, 2010; Ruiz-Campos, 2017).

The future effects of the climate on the distribution of $O$. m. nelsoni demand the recording and assessment of water temperature variations in their habitats on a daily, monthly, and annual basis in the SSPM.

The aim of this study was to measure the daily, sea- sonal, and annual variability of the water temperature in streams of the Sierra San Pedro Mártir, Baja California, Mexico (period of 1996 to 2019), inhabited by the endemic rainbow trout, Oncorhynchus mykiss nelsoni. These data determined the seasonal thermal interval and daily duration of summer temperatures above the thermal threshold for this trout subspecies $\left(\geq 28^{\circ} \mathrm{C}\right)$ at different elevations.

\section{Study area}

The present study was conducted in three-second order streams on the western slope of the SSPM, two located in the Santo Domingo river basin (La Grulla Creek and San Antonio de Murillos Creek) and one in the San Rafael river basin (San Rafael Creek), at an altitude ranging from 553 to 2,080 $\mathrm{m}$ asl (Fig. 1). The study sites were selected based on the known presence of the San Pedro Martir trout (Ruiz-Campos, 2017), as monitored for population density and status from 1987 to the present day.

The regional climate is subhumid with an average annual temperature and precipitation of $7{ }^{\circ} \mathrm{C}$ and $400 \mathrm{~mm}$, respectively (García and Mosiño, 1968; Álvarez and Maisterrena, 1977; Álvarez, 1985). The Santo Domingo river basin is the largest in the SSPM (Ruiz-Campos, 1991), with its six tributaries (La Grulla, El Potrero, Valladares, Santa Cruz, La Zanja, and San Antonio de Murillos), while the tributaries of the San Rafael river basin are the La Fresa, Vallecitos, and Agua Zarca creeks (Ruiz-Campos, 2017). These first and second order streams are perennial, with maximum flow presenting during the winter rainy season (Ruiz-Campos, 2017), and mainly shallow ( $<0.5 \mathrm{~m}$ deep), although some of their pools can be as deep as $1.5 \mathrm{~m}$ (RuizCampos, 1991). The environmental temperature is highly variable, with minimum and maximum values of $-12^{\circ} \mathrm{C}$ in winter and $35^{\circ} \mathrm{C}$ in summer, respectively (Reyes-Coca and García-López, 1991). The arboreal riparian vegetation is dominated by Populus fremotii, Platanus racemosa and Salix lasiolepis, bushy species by Baccharis salicifolia, and aquatic macrophytes by Potamogeton natans and Ceratophyllum demersum (Ruiz-Campos, 2017).

\section{METHODS}

The water temperatures were recorded in those sites where the endemic rainbow trout $O$. mykiss nelsoni has been previously reported (Ruiz-Campos and Pister, 1995; Ruiz-Campos et al., 2014), at three different elevations in the SSPM (553 m asl at San Antonio de Murillos Creek, $1,220 \mathrm{~m}$ asl at San Rafael Creek, and 2,080 $\mathrm{m}$ asl at La Grulla Creek) between 1996 and 2019. The sites of La Grulla and San Antonio de Murillos represent the altitudinal range of distribution of this subspecies (Ruiz-Campos, 2017). Two to three submersible thermometers 
(HOBO Brand Pendant, Model UA-002-08, $\pm 0.01{ }^{\circ} \mathrm{C}$ ) were used at each study site, where each thermometer was placed on the stream bed, mainly in a shaded pool at a depth $>0.4 \mathrm{~m}$, and then held in place with steel wire affixed to a tree trunk. Thermographs were then used to record the water temperature at $1 \mathrm{~h}$-intervals for at least one year, at the end of which, each thermograph was removed and immediately replaced with another thermograph pre-programed to continue recording the water temperature.

At the La Grulla and the San Rafael sites, the water temperature was measured in two periods; $1999-2000$ and 2015-2019 at La Grulla, and 1996-1997 and 2014-2015 at San Rafael. At the San Antonio de Murillos site, temperature was measured in only one period, 2014-2015.

The data was retrieved from each thermometer via the

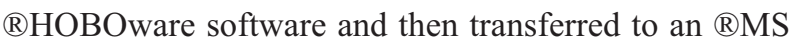
Excel 2016 file for analysis and interpretation on a daily, monthly, and annual basis, establishing the minimum, maximum, and average values for the three sites.
With water temperatures $\geq 28^{\circ} \mathrm{C}$ known to be lethal for southern rainbow trout populations in North America (Kammerer and Heppell, 2013a; Matthews and Berg, 1997). The present study the total number of hours in which temperatures equal to, or was above $28^{\circ} \mathrm{C}$, was calculated.

At the La Grulla site, one way-ANOVA tests were used to compare the daily average temperature values among the three years (1999, 2016 and 2017), while, at the San Rafael site, a Student's $t$-test was used to compare the average daily values for the two years in which measurements were taken (1996 and 2014) (Sokal and Rohfl, 1981). At the San Antonio de Murillos site, no statistical comparison was performed because only 1 year of measurements was recorded. The average daily water temperatures at each site were statistically compared for each summer in which the study was conducted.

Three climate prediction models based on water temperature records were used to predict the temperatures at the three study sites: the GFDL R30 model from the Geophysical Fluid Dynamics Laboratory (Delworth et al.,

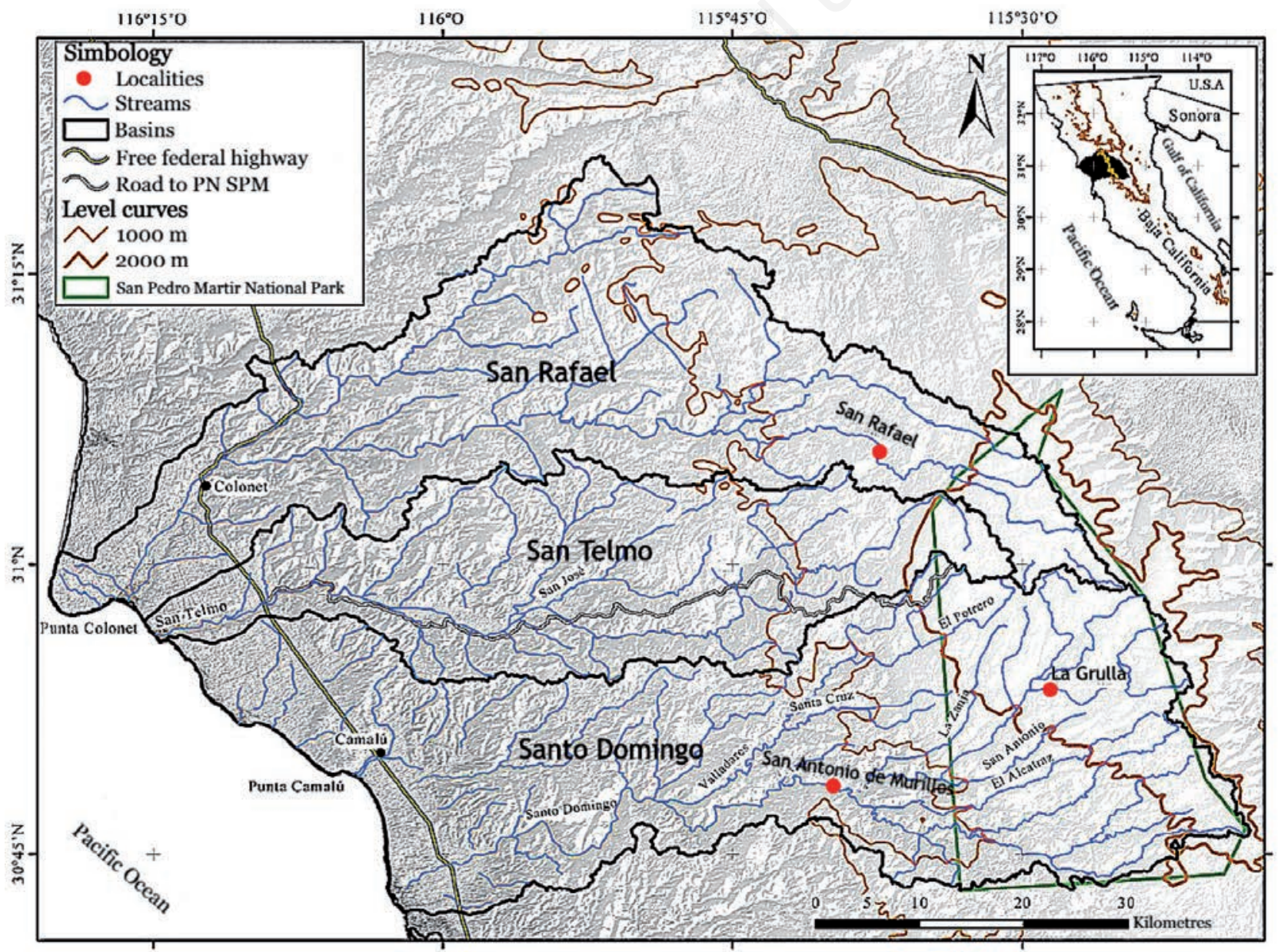

Fig. 1. Surface hydrology of the western slope of the SSPM, Baja California, Mexico, showing the boundaries of the basins and study sites (La Grulla, San Rafael and San Antonio de Murillos creeks). 
2002); the HadCM3 model from the Hadley Center, which was also used by the United Nations Framework Convention for Climate Change (Pope et al., 2000; Conde et al., 2011); and, the Mote model (Mote et al., 2003), which is based on the analysis of eight climate models of the global oceanic atmosphere available through the IPCC Data Distribution Center. The three models were used to project temperatures for the years 2025 and 2050, based on the A2 emissions scenario (Nakicenovic et al., 2000), and linked to the water temperature of the streams in order to determine trends and identify the times and places in which temperatures $\geq 28^{\circ} \mathrm{C}$ were present.

The first prediction, generated using the GFDL R30 model, was a temperature increase of $0.6^{\circ} \mathrm{C}$ for the year 2025 and $0.95^{\circ} \mathrm{C}$ for the year 2050 , while the second, based on the HadCM3 model, produced a temperature increase of $0.45^{\circ} \mathrm{C}$ and $0.85^{\circ} \mathrm{C}$ for the years 2025 and 2050 , respectively. Finally, the Mote model predicted a global increase of $0.75^{\circ} \mathrm{C}$ for the year 2025 and $2^{\circ} \mathrm{C}$ for the year 2050. The last complete annual temperature records were used for the predictive modeling, corresponding to 2016 for La Grulla Creek and 2014 and 2015 for San Rafael and San Antonio de Murillos creeks.

The elevation ( $\mathrm{m}$ asl) in the Santo Domingo river basin (San Antonio de Murillos and La Grulla creeks), where the water temperatures are predicted to remain below the lethal temperature for this trout subspecies by the years 2025 and 2050, was estimated based on the average values (both daily and hourly) generated by the three models. The predicted altitude was calculated as $\mathrm{y}$ $=\mathrm{n}+\mathrm{m} * \mathrm{x}$, where: $\mathrm{y}=$ calculated altitude; $\mathrm{x}=$ average water temperature; and, $n$ and $m$ are the intercept and slope, respectively, of the linear regression. Both constants, $n$ and $m$, were assessed using a $2 \times 2$ system of linear equations (Lehmann, 1986).

\section{RESULTS}

\section{Daily, monthly, and annual temperature variations}

\section{La Grulla Creek}

The water temperature in 1-hour intervals each day show a similar distribution pattern for each year (Fig. 2A). The lowest temperature $\left(0.12^{\circ} \mathrm{C}\right)$ was recorded on $23 \mathrm{Jan}$ uary 2017, at 08:00:07 h, while the highest temperature $\left(17^{\circ} \mathrm{C}\right)$ was recorded on 8 September 2015, at 23:00:07 h. The average temperature between 2015 and 2019 was $10.36 \pm 4.09^{\circ} \mathrm{C}$. No temperatures $\geq 28^{\circ} \mathrm{C}$ were recorded in this period.

The comparison of average daily water temperatures between two periods (June 1999-May 2000 and August 2015-April 2019) is shown in Fig. 2B. The lowest average daily temperature in the first period $\left(5.56^{\circ} \mathrm{C}\right)$ was calculated on 8 March 2000 and the highest $\left(14.9^{\circ} \mathrm{C}\right)$ on 13 July
1999 , while the average temperature was $11.91 \pm 1.73^{\circ} \mathrm{C}$. The lowest average daily water temperature in the second period $\left(0.52^{\circ} \mathrm{C}\right)$ was calculated on 21 January 2017 and the highest $\left(16.7^{\circ} \mathrm{C}\right)$ on $31 \mathrm{July} 2016$, while the average temperature during this period was $10.36 \pm 4^{\circ} \mathrm{C}$. A comparison of the temperatures calculated in the two periods (Fig. 2B) shows a greater range of variation between the lowest and highest temperatures in recent years, namely a greater difference in the average daily temperatures calculated for the different seasons of the year.

Statistical analysis was performed on the summer temperature records, based on the average daily values obtained at the study sites. At the La Grulla site, the average daily temperature was significantly different depending on the year $\left(1999\right.$ : mean $=13.77 \pm 0.44^{\circ} \mathrm{C} ; 2016$ : mean $=$ $15.39 \pm 0.96^{\circ} \mathrm{C}$; and 2017 : mean $=15.34 \pm 0.53^{\circ} \mathrm{C}$; one-way ANOVA, $F=162.03, \mathrm{P}<0.001)$.

\section{San Rafael Creek}

The water temperature was recorded at $1 \mathrm{~h}$ intervals at the San Rafael site (1,220 m asl) from February 2014 to February 2015 (Fig. 3A), with the lowest temperature $\left(3.05^{\circ} \mathrm{C}\right)$ recorded on 1 January 2015 and the highest $\left(27.17^{\circ} \mathrm{C}\right)$ on 8 June 2014 . The average temperature during this period was $14.58 \pm 4.9^{\circ} \mathrm{C}$, while no temperatures $\geq 28^{\circ} \mathrm{C}$ were detected.

The comparison of average daily water temperatures between two periods (May 1996-May 1997 and February 2014-February 2015) is shown in figure 3B. The lowest average daily temperature in the first period $\left(3.72^{\circ} \mathrm{C}\right)$ was calculated on 7 January 1997 and the highest $\left(24.04^{\circ} \mathrm{C}\right)$ was on 31 July 1996, while the average temperature was $14.704 \pm 5.69^{\circ} \mathrm{C}$. Moreover, the lowest average daily temperature in the second period $\left(4.01^{\circ} \mathrm{C}\right)$ was calculated on 2 January 2015 and the highest $\left(23.17^{\circ} \mathrm{C}\right)$ was on 7 July 2014 , while the average temperature was $14.58 \pm 4.75^{\circ} \mathrm{C}$.

The average temperature calculated during the summer at the San Rafael site was significantly different depending on the year $\left(1996\right.$ : mean $=21.35 \pm 2.03^{\circ} \mathrm{C}$ and 2014: mean $=20.35 \pm 1.67^{\circ} \mathrm{C}$; Student's $t$-test, $\mathrm{t}=4.46$, $\mathrm{P}<0.001$ ).

\section{San Antonio de Murillos Creek}

The temperature values recorded at $1 \mathrm{~h}$ intervals at this site (553 m asl) from May 2014 to April 2015 are displayed in Fig. 4A. The lowest temperature value $\left(5.19^{\circ} \mathrm{C}\right)$ was recorded on 2 January 2015, while the highest $\left(30.66^{\circ} \mathrm{C}\right)$ was recorded on 15 August 2014 . The average temperature during this period was $19.31 \pm 5.73{ }^{\circ} \mathrm{C}$, with a high frequency of days with a temperature $\geq 28^{\circ} \mathrm{Cob}$ served between 1 June 2014 and 26 September 2014, giving an accumulated time of $365 \mathrm{~h}$. This was the only site at which the presence of trout coincided with daily records 
of high temperatures $\left(\geq 28^{\circ} \mathrm{C}\right)$, which is explained by its low elevation.

Fig. 4B shows the average daily water temperature during from May 2014 to April 2015, with the lowest average daily value $\left(6.91^{\circ} \mathrm{C}\right)$ calculated on 2 January 2015 and the highest average daily value $(27.09 \mathrm{C})$ calculated on 17 August 2014. The average temperature for this entire period was $19.32 \pm 5.41^{\circ} \mathrm{C}$.

\section{Water temperature scenarios at the stream sites}

The models applied were based on the water temperatures recorded at 1-hour intervals at the three sites between 2014 and 2016 and were used to determine the amplitude, time (in hours), and the sites with temperatures $\geq 28^{\circ} \mathrm{C}$, which are lethal for the rainbow trout subspecies of interest.

At the La Grulla site, no temperature values higher than $\geq 28^{\circ} \mathrm{C}$ were predicted for the years 2025 and 2050 by the three global warming models, based on the 1-hour temperature recordings (Fig. 5A).

At the San Rafael site, no temperature values $\geq 28^{\circ} \mathrm{C}$ were predicted for the year 2025 (Fig. 5B), while for the year 2050, the three models predicted values above this threshold. The model (Mote 2050) using an increase of $2{ }^{\circ} \mathrm{C}$ predicted the highest number of extreme events, predicting a total of 53 hours of temperatures $\geq 28^{\circ} \mathrm{C}$ between

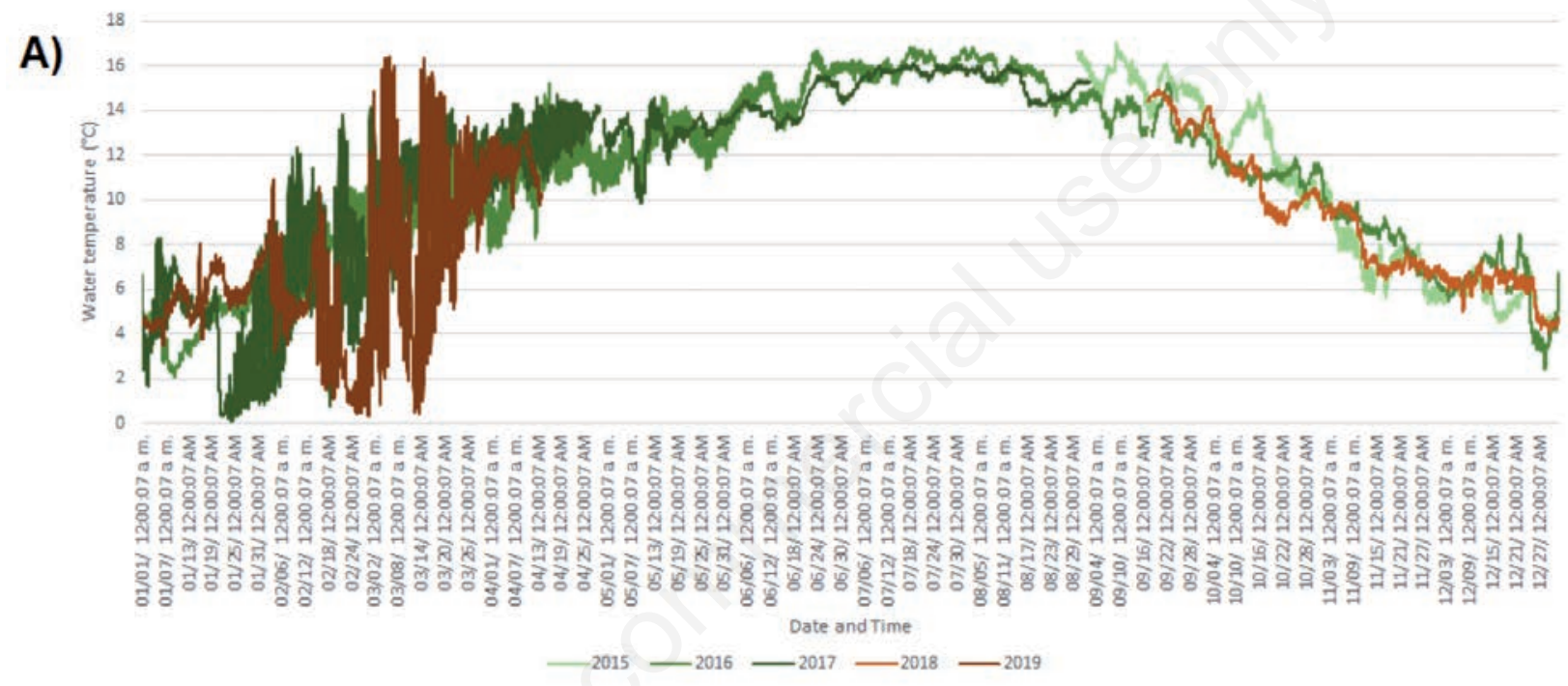

B)

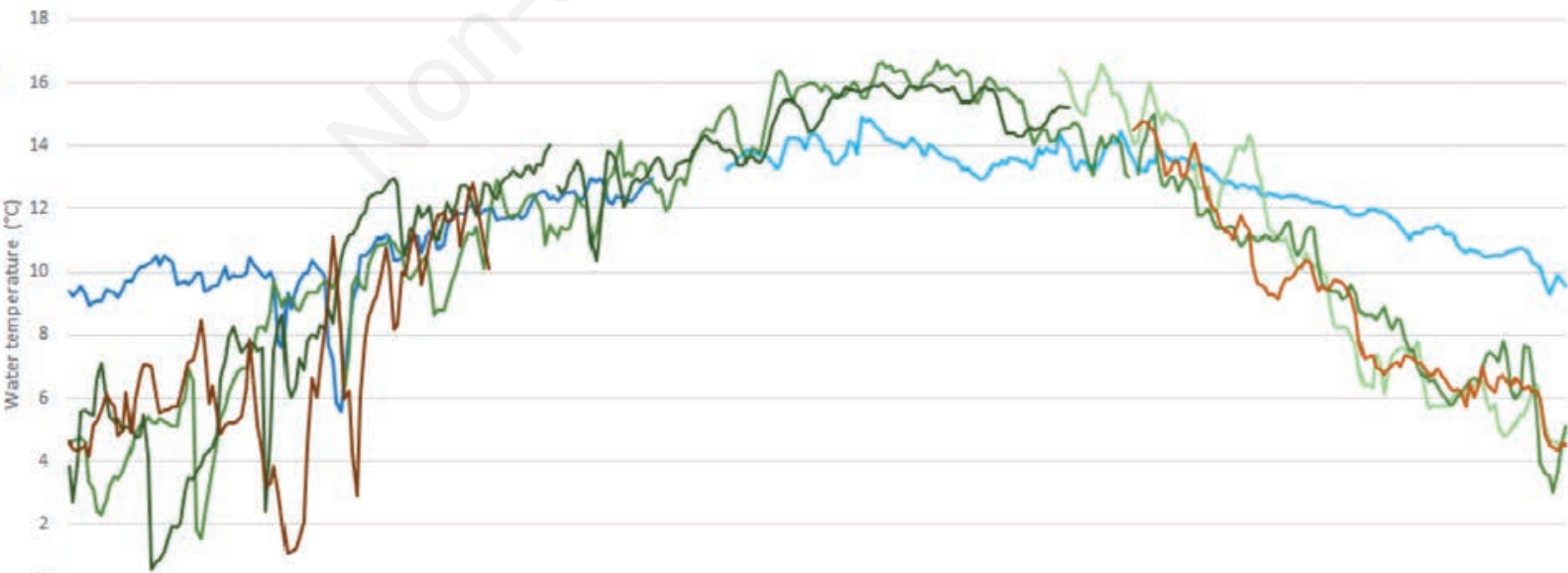

0

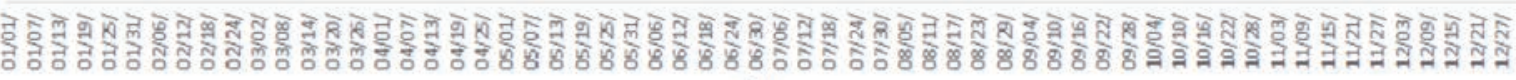
Date

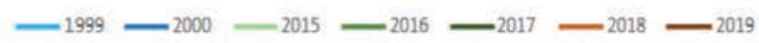

Fig. 2. A) Water temperature recorded with a dual meter at 1-hour intervals, from August 2014 to April 2019. B) Average daily temperature from June 1999 to May 2000 and August 2015 to April 2019, at an altitude of 2,080 m asl, in La Grulla Creek, SSPM, Baja California. 
June 29 and August 15, 2050. In the model (HadCM3 2050), using an increase of $0.85^{\circ} \mathrm{C}$ ), predicted the least number of extreme termal events $\left(\geq 28^{\circ} \mathrm{C}\right)$ with a total of three hours between June 30 and August 8, 2050 (Tab. 1).

Fig. 6 shows the water temperature at the San Rafael site on the same date in summer (28 July) for the years 1993 and 2014 as well as the temperature predicted for the same date in 2050 by the third model (Mote 2050) $\left(+2^{\circ} \mathrm{C}\right)$. This date (28 July) was chosen based on water temperature records for 24 July 1993, which were compared with recent (2014) and predicted data (2050) for this date. A trend of increasing water temperatures was found at any time on the same date for the three different years, reaching, by the year 2050 , temperatures $\left(\geq 28^{\circ} \mathrm{C}\right)$ that are lethal for the survival of rainbow trout subspecies.

Based on the three models of predictions for the San Antonio de Murillos site, a significant and lethal increase in water temperature $\left(\geq 28^{\circ} \mathrm{C}\right)$ is expected to occur in the habitat for the endemic trout in the years 2025 and 2050 (Fig. 5C). For the year 2025, the model (Mote 2025) (increase of $0.75^{\circ} \mathrm{C}$ ) predicted the highest frequency of extreme temperatures $\left(\geq 28^{\circ} \mathrm{C}\right)$ with a total of $610 \mathrm{~h}$ between June 29 and September 26 (Tab. 1); while the model (HadCM3 2025) with an increase of $0.45^{\circ} \mathrm{C}$ predicted a lesser number of hours (493) with lethal temperatures between May 31 and June 26 (Tab. 1).

For the year 2050, at this same site, the Mote 2050 model (increase of $2^{\circ} \mathrm{C}$ ) predicted the highest number of

A)

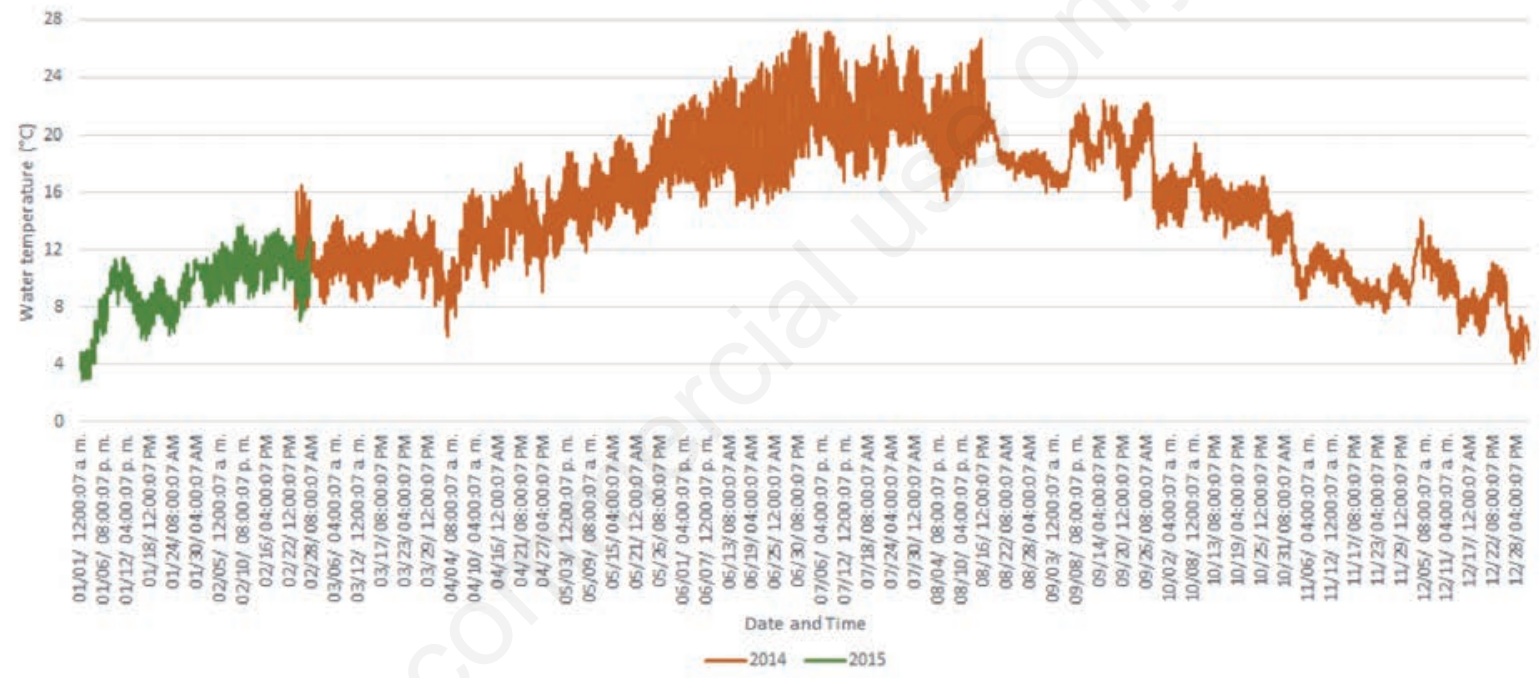

B)

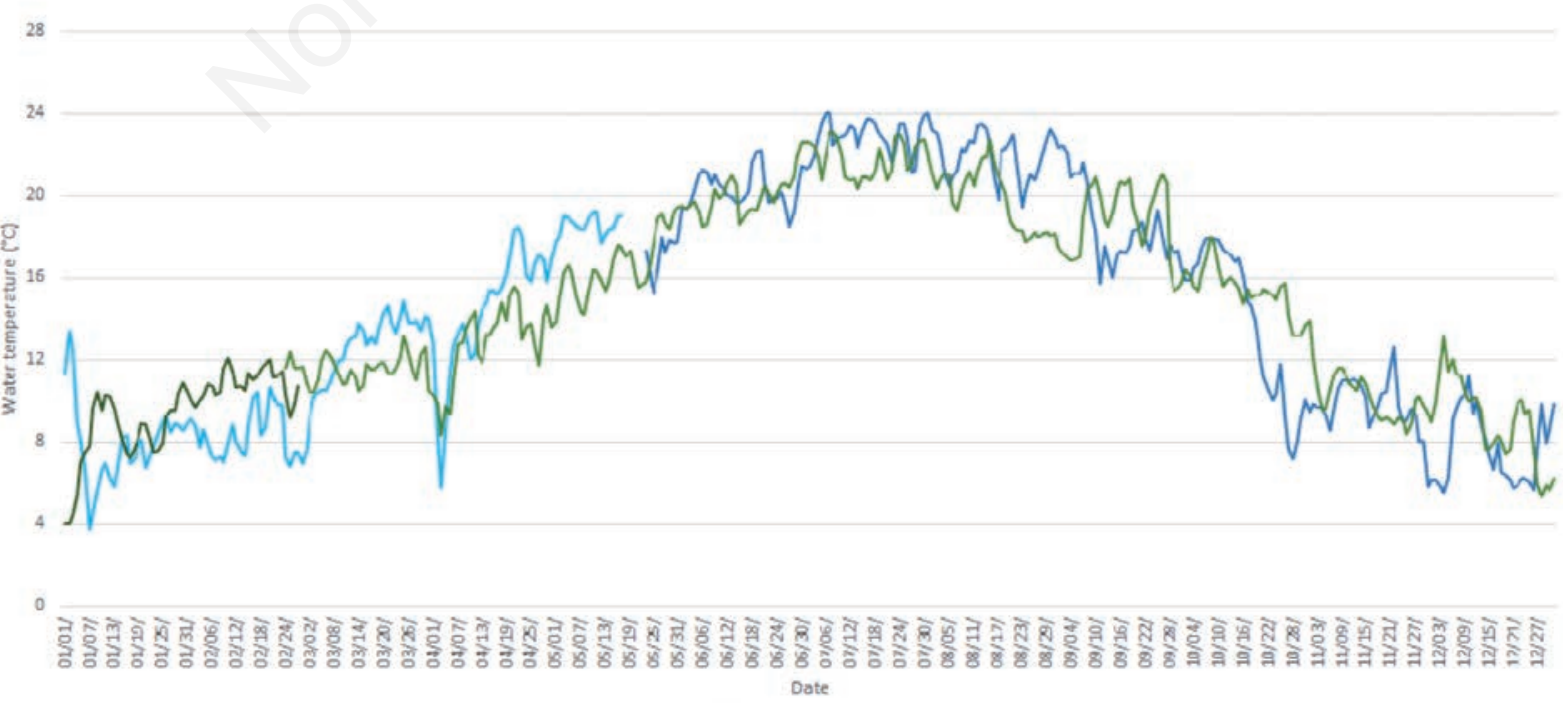

Fig. 3. A) Water temperature recorded with a dual meter at 1-hour intervals, from 2014 to February 2015. B) Daily average temperature from May 1996 to February 2015, at an altitude of 1,220 m asl, in San Rafael Creek, SSPM, Baja California. 
accumulated hours with temperatures $\geq 28^{\circ} \mathrm{C}$, giving a total of 1114 between May 3 and September 27. The HadCM3 2050 model with an increase of $0.85^{\circ} \mathrm{C}$ predicted the lowest number of hours above the $28^{\circ} \mathrm{C}$, giving a total of $640 \mathrm{ac}-$ cumulated hours, from May 26 to September 26 (Tab. 1). The highest frequency of $\geq 28^{\circ} \mathrm{C}$ events were identified at San Antonio de Murillos Creek, the site with the highest incidence of warm temperatures, mainly due to its lower altitude (553 $\mathrm{m}$ asl) than the other two study sites (San Rafael, 1,220 m asl; and La Grulla, 2,080 m asl). The minimum altitude in the SSPM at which daily and hourly average temperature values $\geq 28^{\circ} \mathrm{C}$ would not present in the streams subject to the present research was calculated based on the temperature projections described above.

For the year 2025, a daily average temperature lower than $28^{\circ} \mathrm{C}$ (non-lethal) is predicted to occur at a minimum elevation of $491.04 \mathrm{~m}$ asl, by the least extreme model in the present study $(\mathrm{HadCM} 3 \mathrm{R} 302025)\left(+0.45^{\circ} \mathrm{C}\right)$, while $511.32 \mathrm{~m}$ asl is the minimum altitude at which average daily temperature values $<28^{\circ} \mathrm{C}$ are predicted to occur by the most extreme model (Mote 2025) $\left(+0.75^{\circ} \mathrm{C}\right)$ (Fig. 7A). For the year 2050 , average daily temperatures below $28^{\circ} \mathrm{C}$ are predicted at a minimum elevation of $545.12 \mathrm{~m}$ asl by the HadCM3 model $\left(+0.85^{\circ} \mathrm{C}\right)$ and at $700.57 \mathrm{~m}$ asl by the Mote 2050 model $\left(+2^{\circ} \mathrm{C}\right)$ (Fig. 7B).

Hourly temperatures lower than $28^{\circ} \mathrm{C}$ (non-lethal) are predicted by 2025 at an altitude ranging from 868 (according to HadCM3 2025) to $898 \mathrm{~m}$ asl (according to Mote 2025 , the most extreme model used in the present study) (Fig. 8A). For the year 2050, hourly temperatures below $28^{\circ} \mathrm{C}$ are predicted within a range of 908 (HadCM 2050) and $1028 \mathrm{~m}$ asl (Mote 2050) (Fig. 8B).

\section{DISCUSSION}

In spite of that several studies have projected the effects of increasing temperatures on salmonid distribution considering a broad geographic domain (Nakano et al., 1996; Flebbe et al., 2006; Rieman et al., 2007), our study was done on a regional scale in the western slope of the Sierra San Pedro Mártir (northwestern Mexico) to predict the effects of temperature increases $\left(0.45\right.$ to $\left.2.0^{\circ} \mathrm{C}\right)$ on the altitudinal distribution of the endemic southern rainbow trout (O. mykiss nelsoni) during the years 2025 and 2050.

The lethal water temperature $\left(\geq 28^{\circ} \mathrm{C}\right)$ for southern rainbow trout in North America (Matthews and Berg, 1997; Kammerer and Heppell, 2013b; Nusslé et al., 2015) was recorded in our study region at the San Antonio de Murillos site (553-560 masl), where the endemic trout reaches its lowest limit of altitudinal distribution (RuizCampos, 2017). In this site, a total of 365 hours with temperatures $\geq 28^{\circ} \mathrm{C}$ were recorded between 1 June 2014 and 26 September 2014. These temperatures above $28^{\circ} \mathrm{C}$ significantly exceeded the duration and intensity of those found to be conducive for the survival of native trout in streams of southern California, USA (Nusslé et al., 2015).

Based on the values discussed above, the San Antonio de Murillos site represents the location most vulnerable to global warming and, therefore, that most likely to generate a displacement in the altitudinal distribution of $O$. m. nelsoni trout to colder habitats upstream (see Rieman et al., 2007). Fish exposed to temperatures above this threshold experience physiological cellular stress, including the synthesis of heat shock proteins (HSP) 30 and 70 (Lund et al., 2002), with levels of the latter increasing during acute thermal exposure (Mesa et al., 2002).

A comparison of the water temperatures at the study site with the highest elevation (La Grulla Creek) between June 1999 and May 2000 and August 2015 and April 2019 revealed a greater seasonal variability in daily average temperature intervals, especially in the summer seasons of the second period. This represents a latent threat not only for endemic trout, but also for other aquatic species that inhabit this mountainous ecosystem, thus coinciding with the effects of global warming projected by the IPCC.

Tab. 1. Number of accumulated hours with water temperatures greater than $\geq 28^{\circ} \mathrm{C}$ in three sites of the Sierra San Pedro Mártir, Baja California, Mexico, based on projections with three different models for the years 2025 and 2050.

\begin{tabular}{|c|c|c|c|c|c|}
\hline \multirow{2}{*}{ Site } & \multirow[t]{2}{*}{ Model } & \multicolumn{2}{|c|}{ Year 2025} & \multicolumn{2}{|c|}{ Year 2050} \\
\hline & & Hours $\geq 28^{\circ} \mathrm{C}$ & Period & Hours $\geq 28^{\circ} \mathrm{C}$ & Period \\
\hline \multirow[t]{3}{*}{ La Grulla } & GFDL R30 & 0 & 0 & 0 & 0 \\
\hline & HadCM3 & 0 & 0 & 0 & 0 \\
\hline & Mote & 0 & 0 & 0 & 0 \\
\hline \multirow[t]{3}{*}{ San Rafael } & GFDL R30 & 0 & 0 & 9 & 30 June-8 August \\
\hline & HadCM3 & 0 & 0 & 3 & 30 June- 8 August \\
\hline & Mote & 0 & 0 & 53 & 29 June-15 August \\
\hline \multirow[t]{3}{*}{ San Antonio de Murillos } & GFDL R30 & 548 & 26 May-26 September & 686 & 26 May-26 June \\
\hline & HadCM3 & 493 & 31 May-26 June & 640 & 26 May-26 September \\
\hline & Mote & 610 & 29 June-26 September & 1,114 & 3 May-27 September \\
\hline
\end{tabular}


It should be noted that the same measurement methodology was used for both aforementioned study periods.

Various climate change scenarios predict an increase in water temperatures, which for the rainbow trout will lead to a higher energy cost if the warmer currents do not produce enough food resources to satisfy its metabolic de-

A)

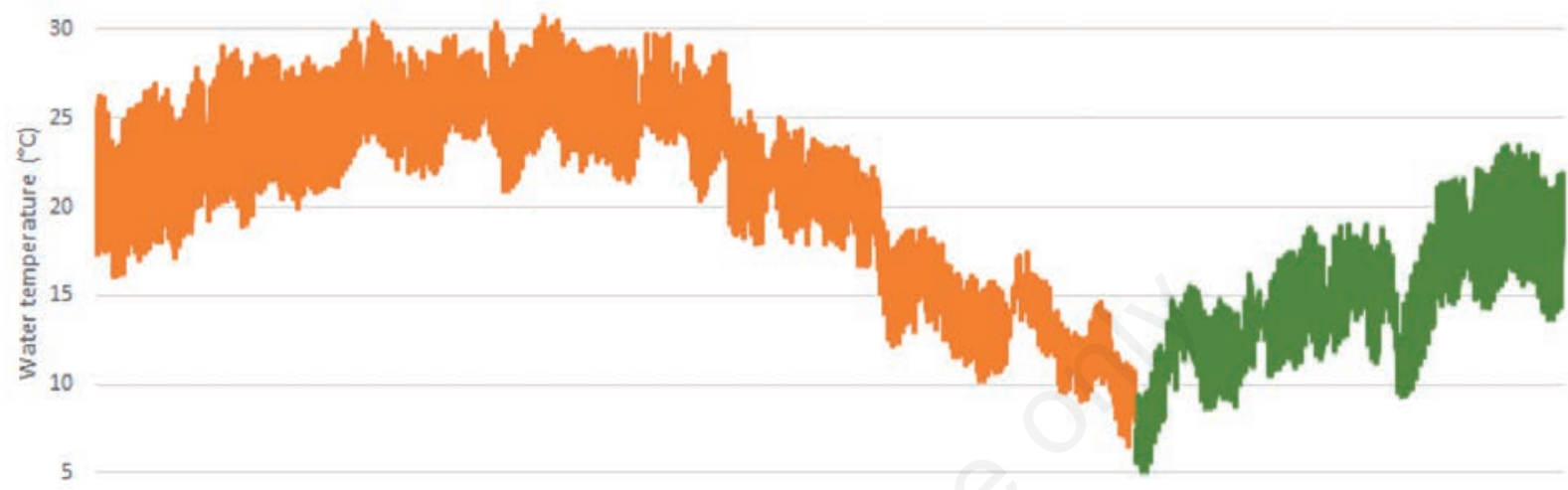

0

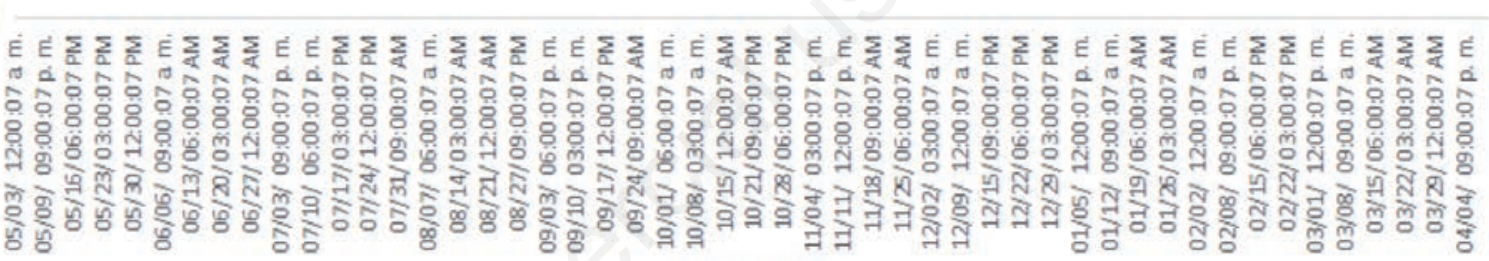

Date and Time

$-2014-2015$

B)

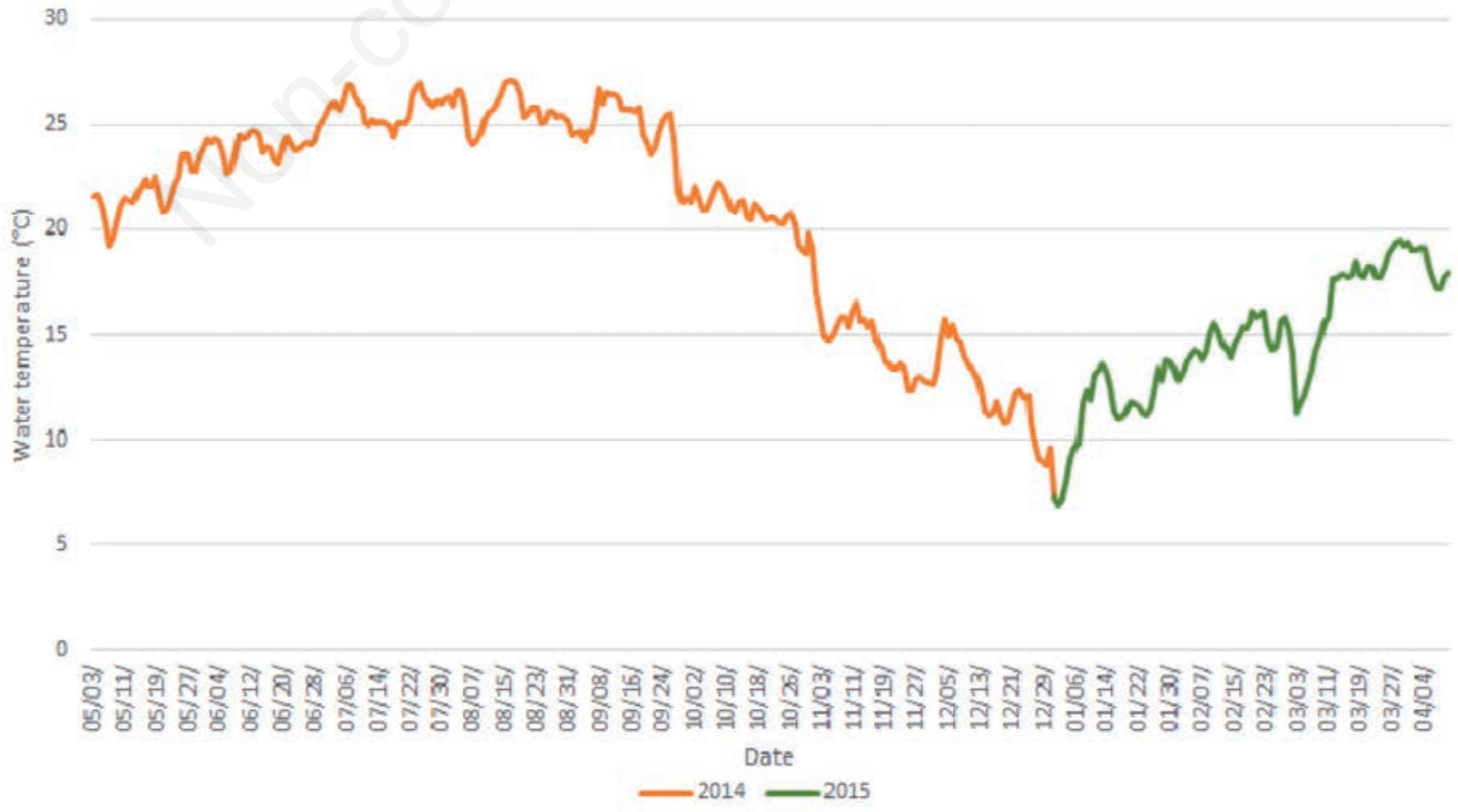

Fig. 4. A) Water temperature recorded with a dual meter at 1-hour intervals from May 2014 to April 2015. B) Average daily temperature from May 2014 to April 2015, at an altitude of 553 m asl, in San Antonio de Murillos Creek, SSPM, Baja California. 


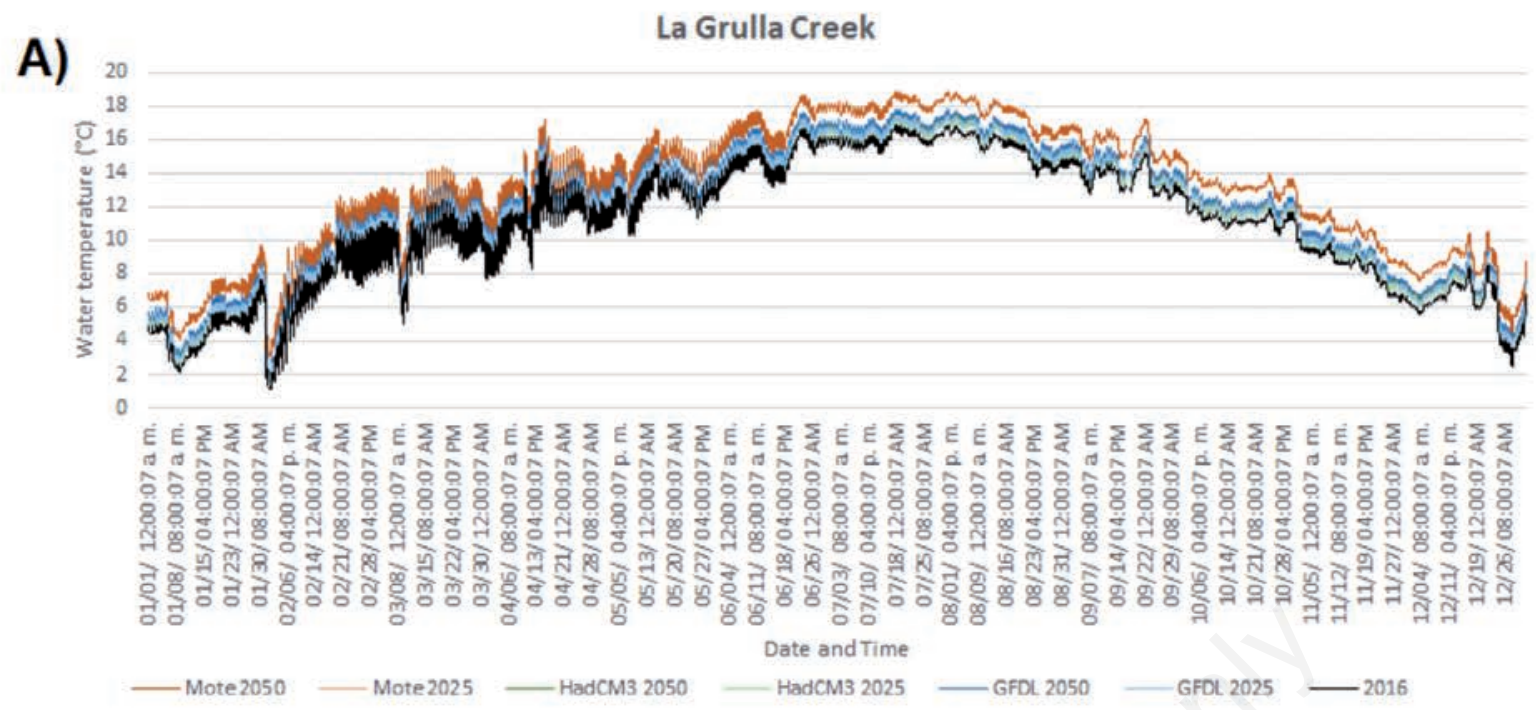

B)

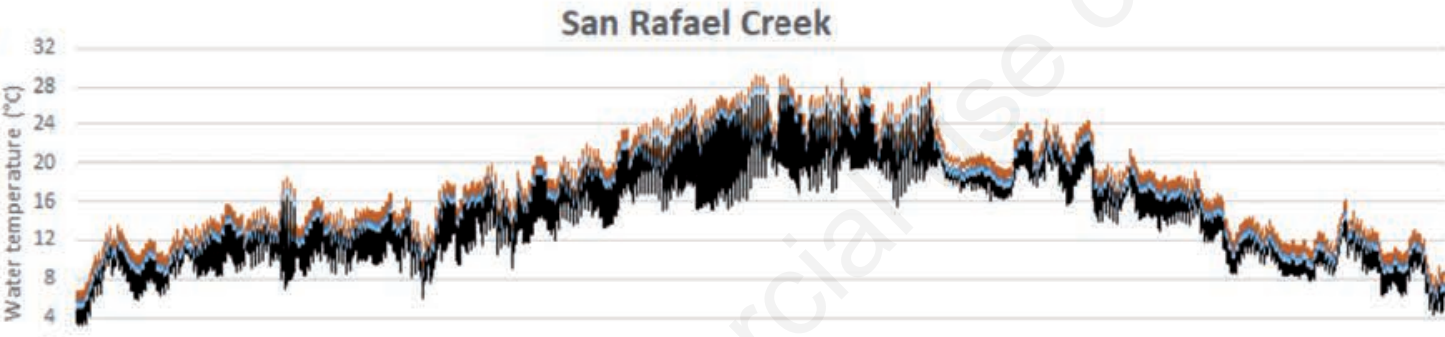

0

E

m

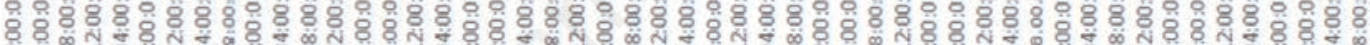

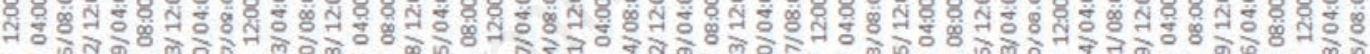

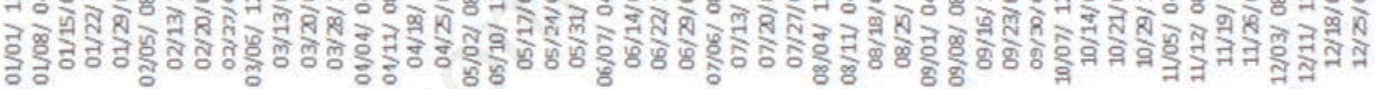

Date and Time

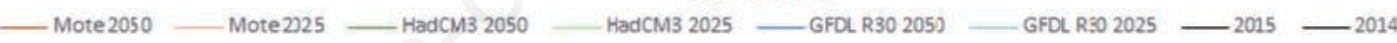

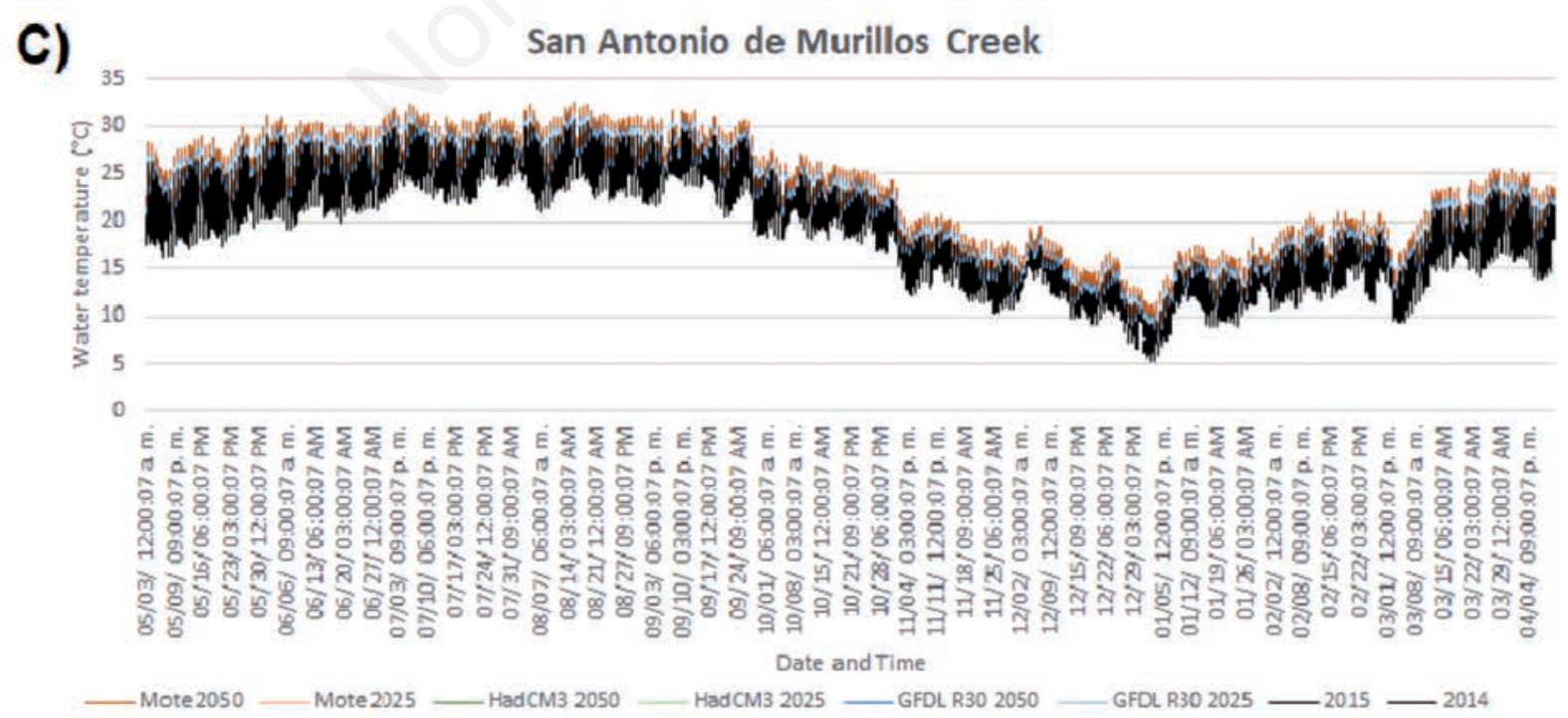

Fig. 5. Temperatures predicted for the years 2025 and 2050 by the climate models GFDL R30, HadCM3, and Mote, for 1-h intervals for La Grulla (A), San Rafael (B), and San Antonio de Murillos (C) creeks, SSPM, Baja California. 
mands, leading to reduced levels of growth in individuals (Battin et al., 2007). This increased temperature will produce changes in the distribution of salmonid populations, thus affecting their ability to withstand tropical storms, especially in the summer (Battin et al., 2007). Furthermore, it is likely that summer temperatures will reach or exceed the levels tolerated by trout, causing higher mortality rates (Crozier et al., 2008) and, thus, enabling non-salmonid species, including potential predators or competitors, to flourish in these thermally modified habitats (Reeves et al., 1987). We showed that an increase between 0.45 and $2.0^{\circ} \mathrm{C}$, the average water temperature during summer daylight hours at $553 \mathrm{~m}$ asl in the type locality of O. m. nelsoni (San Antonio de Murillos Creek) may increase the breadth and duration of the lethal temperature range for this subspecies, as occurs in the rainbow trout populations of southern California, USA, at temperatures $\geq 28^{\circ} \mathrm{C}$ (Nusslé et al., 2015). Therefore, these temperature changes would generate a confinement in this species' altitude distribution range, wherein it is only able to survive in streams at elevations permitting the appropriate thermal range.

The predicted scenarios for the altitudinal distribution of the trout in the study area based on increases of $0.75^{\circ} \mathrm{C}$ and $2.0^{\circ} \mathrm{C}$ in the years 2025 and 2050 , respectively, showing in both cases a reduction of its distributional range of $21-23 \%$ for 2025 and $23-31 \%$ for 2050 . This condition will limit its presence in the type locality situated at an elevation of $553 \mathrm{~m}$.

Finally, a strategy for mitigation of the future effects of the increased frequency of lethal summer temperatures on the survival of the endemic trout subspecies in the type locality, might be achieved by means of the conditioning of habitat via expanded use of deep pools as thermal refuges for these trout (Matthews and Berg, 1997).

\section{ACKNOWLEDGMENTS}

The present study received funds from various agencies and institutions: National Council of Science and Technology, Mexico (agreements: PCECCNA-050389, P22OCCOR-892393, 0340-N9107, 33528-V, 431100-51993PN); Secretary of Public Education (agreements C88-01-081 and C-89-01-185); National Commission for

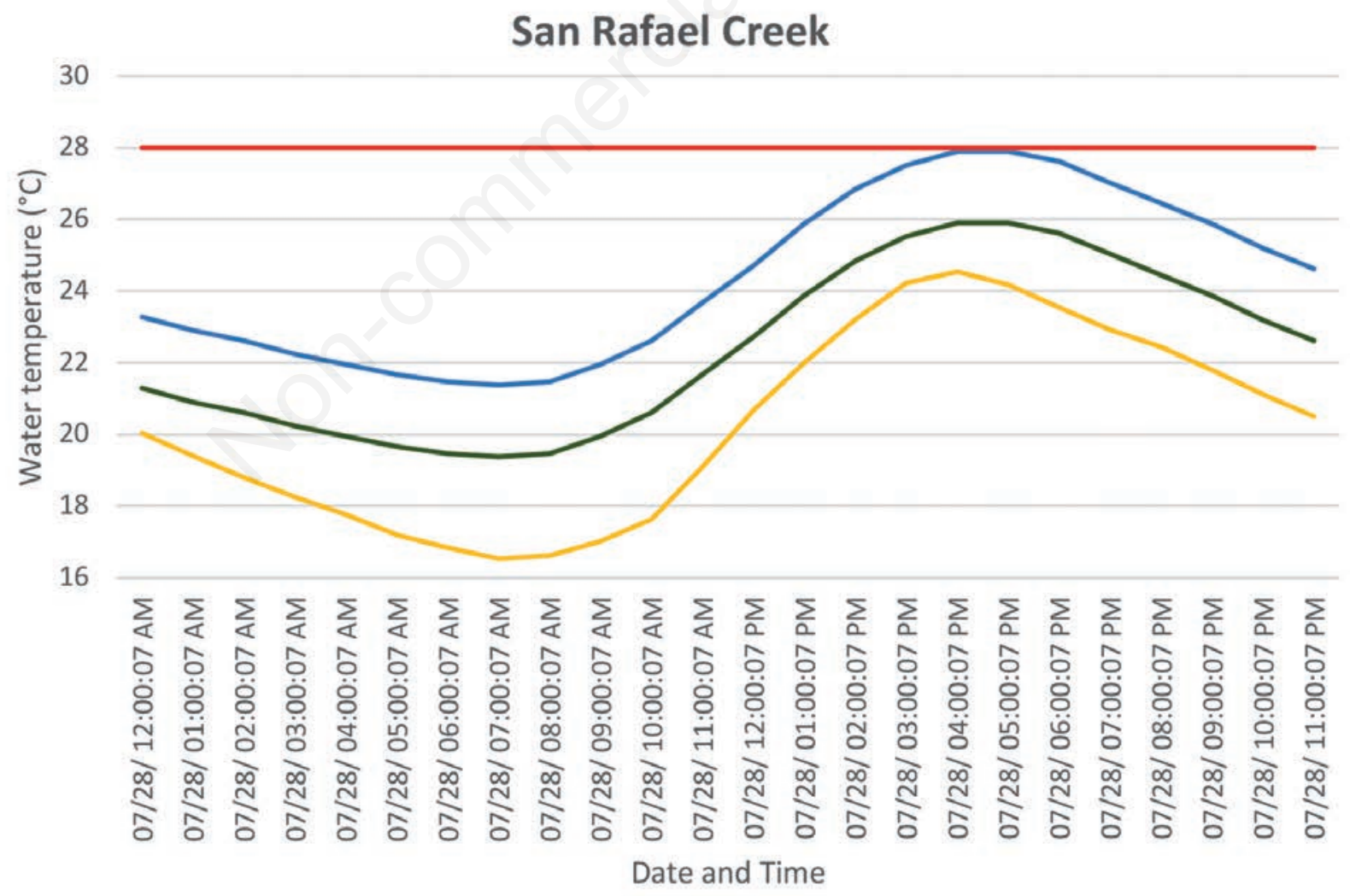

-1993 -2014 - Mote $2050 \longrightarrow$ Lethal temperature

Fig. 6. Water temperatures recorded at 1-hour intervals on 28 July for the years 1993 and 2014, and those projected for the year 2050 with the climate model (Mote) used for San Rafael Creek, SSPM, Baja California. 

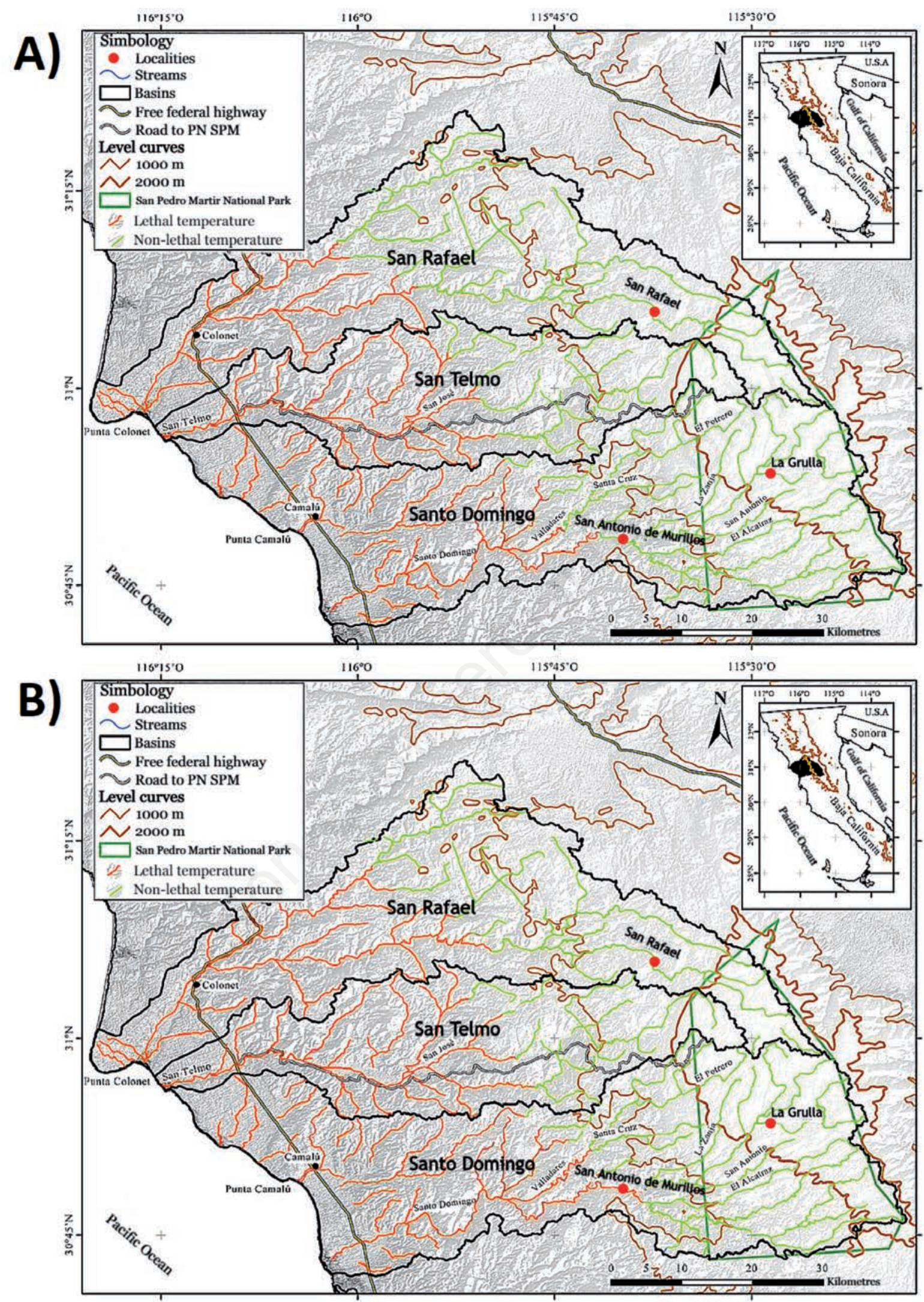

Fig. 7. Minimum altitude with daily average temperature values below $28^{\circ} \mathrm{C}$ in the Santo Domingo, San Telmo, and San Rafael river basins, as predicted by the Mote model for the years 2025 (A) and 2050 (B). 

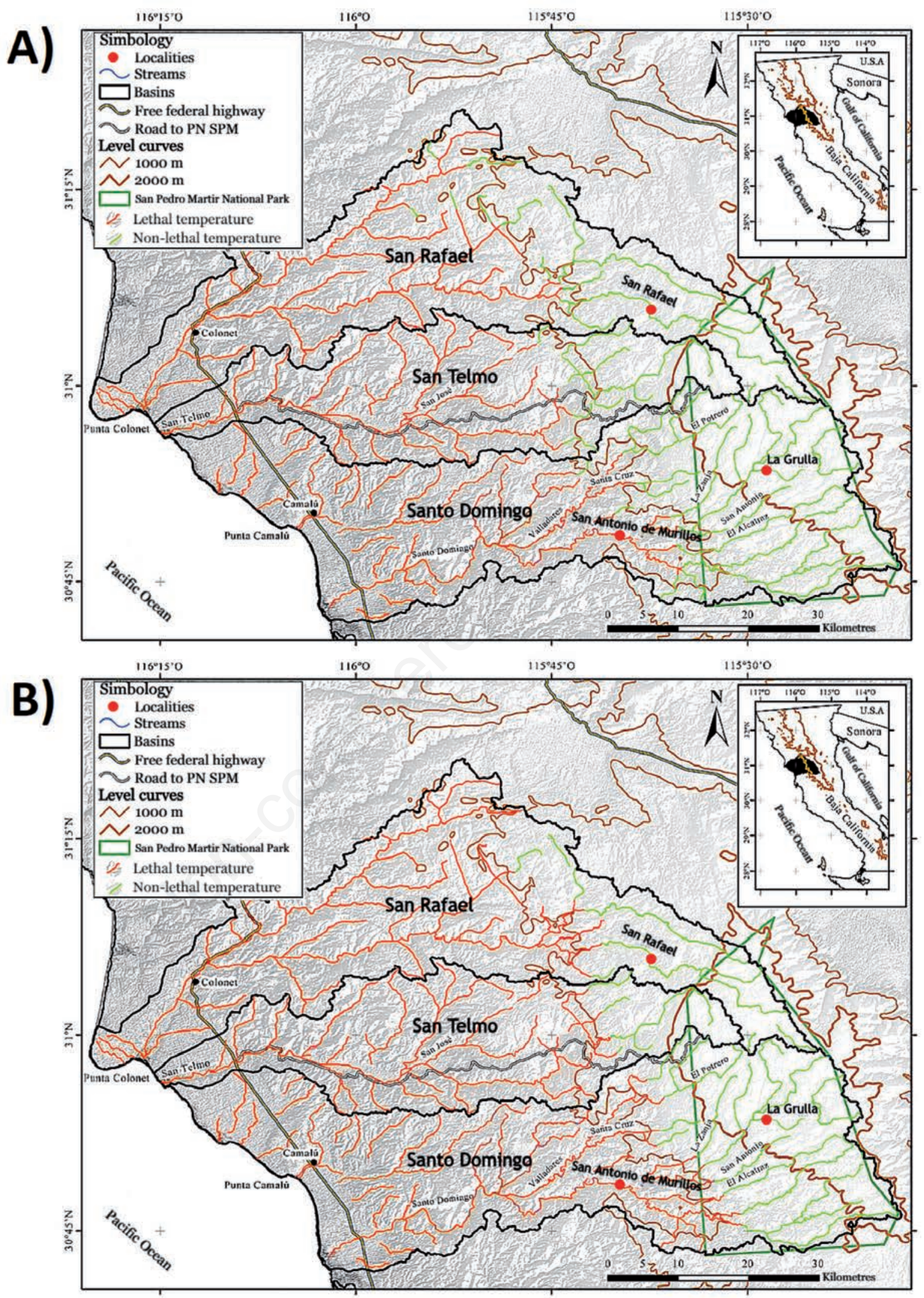

Fig. 8. Minimum altitude with hourly temperature values below $28^{\circ} \mathrm{C}$ in the Santo Domingo, San Telmo, and San Rafael river basins, as predicted by the Mote model for the years 2025 (A) and 2050 (B). 
the Knowledge and Use of Biodiversity (agreements S087, DC007 and W028); and, the General Directorate for Postgraduate Study and Research at the Autonomous University of Baja California (agreements 0148 and 277). The final section was supported by the Autonomous University of Baja California (1 $17^{\text {th }}$ edition of the research project list) and the National Commission for Protected Natural Areas (agreement: PROCER / CCER DRPBCPN / 03/2016). We thank A. Andreu, M. Solís, P. Díaz, E. Flores, C. Ballesteros, A. Guevara, S. Celaya, Á. Jiménez, S. Martínez, J. Villareal, and D. De La Barrera for their support in the field sampling. We are grateful to R. Arce and I. Salazar for their support in the transportation of equipment and personnel on mules and horses, respectively, to and from the study sites. An anonymous reviewer made very useful comments and suggestions that improved the content of the manuscript.

\section{REFERENCES}

Abatzoglou JT, Redmond KT, 2007. Asymmetry between trends in spring and autumn temperature and circulation regimes over western North America. Geophysical Research Letters 34:L18808.

Alvarez M, 1985. Climatology of the Sierra San Pedro Mártir. Proceedings of the Desert Fishes Council 13:331-342.

Alvarez M, Maisterrena J, 1977. Meteorological and climatological observations in the Sierra San Pedro Martir. Rev. Mex. Astron. Astrophys. 2 (43).

Barnett TP, Pierce DW, Hidalgo HG, Bonfils C, Santer BD, Das T, Bala G, Wood AW, Nozawa T, Mirin AA, Cayan DR, Dettinger MD, 2008. Human induced changes in the hydrology of the western United States. Science 319:1080-1083.

Bartholow JM, 2005. Recent water temperature trends in the lower Klamath River, California. N. Am. J. Fish Manage. 25:152-162.

Battin J., Wiley MW, Ruchelshaus MH, Palmer RN, Korb E, Bartz KK, Imaki H, 2007. Projected impacts of climate change on salmon habitat restoration. Proc. Natl. Acad. Sci. USA 104 6720-6725.

Behnke RJ, 2002. Trout and salmon of North America. The Free Press, New York.

Bidgood BF, Berst AH, 1969. Lethal temperatures for Great Lakes rainbow trout. J. Fish. Res. Board. Can. 26:456-459.

Bisson PA, Davis GE, 1976. Production of juvenile chinook salmon, Oncorhynchus tshawytscha, in a heated model stream. Fish. Bull. 74:763-774.

Brannon EL, Powell MS, Quinn TP, Talbot A, 2004. Population structure of Columbia River Basin Chinook salmon and steelhead trout. Revi. Fish. Sci. 12:99-232.

Chen JQ, Snow M, Lawrence CS, Church AR, Narum SR, Devlin RH, Farrell AP, 2015. Selection for upper thermal tolerance in rainbow trout (Oncorhynchus mykiss Walbaum). J. Exp. Biol. 218:803-812.

Christensen JH, Christensen OB, 2003. Climate modelling: Severe summertime flooding in Europe. Nature 421:805-806.

Conde DA, Flesness N, Colchero F, Jones OR, Scheuerlein A,
2011. An emerging role of zoos to conserve biodiversity. Science 331: 390-1391.

Crozier L, Zabel RW, Hamlet AF, 2008. Predicting differential effects of climate change at the population level with lifecycle models of spring Chinook salmon. Glob. Change Biol. 14:236-249.

Crozier LG, Zabel RW, 2006. Climate impacts at multiple scales: evidence for differential population responses in juvenile Chinook salmon. J. Anim. Ecol. 75:1100-1109.

Daufresne MD, Boet P, 2007. Climate change impacts on structure and diversity of fish communities in rivers. Glob. Change Biol. 13:2467-2478.

Delgadillo-Rodríguez J, 1992. [Florística and ecología del norte de Baja California].[in Spanish]. Universidad Autónoma de Baja California, Mexicali, Mexico.

Delworth TL, Stouffer RJ, Dixon KW, Spelman MJ, Knutson TR, Broccoli AJ, Kushner PJ, Wetherald RT, 2002. Simulation of climate variability and change by the GFDL R30 coupled climate model. Climate Dynamics 19:555-574.

Evermann BW, 1908. Descriptions of a new species of trout (Salmo nelsoni) and a new cyprinodont (Fundulus meeki) with notes on other fishes from Lower California. P. of Biol. Soc. Wash. 21:19-30.

Flebbe PA, Roghair LD, Bruggink JL, 2006. Spatial modeling to project southern Appalachian trout distribution in a warmer climate. T. Am. Fish. Soc. 135:1371-1382.

García E, Mosiño P, 1968. The climates of Baja California. Report 1966-1967. Instituto de Geofísica-Universidad Nacional Autónoma de México, México.

Hamlet AF, Lettenmaier DP, 2007. Effects of 20th century warming and climate variability on flood risk in the western U.S. Water Resour. Res.h 43:W06427.

Heino J., Virkkala R, Toivonen, H, 2009. Climate change and freshwater biodiversity: detected patterns, future trends and adaptations in northern regions. Biol. Rev. 84:39-54.

IPCC (Intergovernmental Panel on Climate Change), 2007. Climate change 2007: the physical science basis. Available from: http: //www.ipcc.chi

Isaak DJ, Hubert WA, 2001. A hypothesis about factors that affect maximum summer stream temperatures across montane landscapes. J. Am. Water Resour. Assoc. 37:351-366.

Istanbulluoglu E, Tarboton DG, Pack RT, Luce CH, 2004. Modeling of the interactions between forest vegetation, disturbances, and sediment yields. J. Geophys. Res. 109:F01009.

Jager HI, Van Winkle W, Holcomb BD, 1999. Would hydrologic climate changes in Sierra Nevada streams influence trout persistence? T. Am. Fish. Soc. 128:222-240.

Jelks HL, Walsh, SJ, Burkhead, NM, Contreras-Balderas, S, Diaz-Pardo, E, Hendrickson, DA, Lyons, J, Mandrak, NE, Mccormick, F, Nelson, JS, Platania, SP, Porter, BA, Renaud, CB, Schmitter-Soto, JJ, Taylor, EB, Warren Jr., ML, 2008. Conservation status of imperiled North American freshwater and diadromous fishes. Fisheries 33:372-407.

Kammerer BD, Heppel SA, 2013a. The effects of semichronic thermal stress on physiological indicators in steelhead. T. Am. Fish. Soc. 142:1299-1307.

Kammerer BD, Heppel SA, 2013b. Individual condition indicators of thermal habitat quality in field populations of Redband Trout (Oncorhynchus mykiss gairdneri). Environ. Biol. Fish. 96:823-835. 
Lehmann CH, 1986. [Geometría analítica].[Book in Spanish]. Editorial Limusa, Mexico.

Leppi JC, DeLuca TH, Harrar S, Running SW, 2010. August stream discharge trends portend impacts of climate change in the northern rockies, p. 24-31. In: R.F. Carline and C. LoSapio (eds.), Conserving wild trout. Proceedings of the Wild Trout X symposium, Bozeman.

Luce CH, Holden Z, 2009. Declining annual streamflow distributions in the Pacific Northwest United States, 1948- 2006. Geophys. Res. Lett. 36:L16401.

Lund SG, Caissie D, Cunjak RA, Vijayan MM, Tufts BL, 2002. The effects of environmental heat stress on heat-shock mRNA and protein expression in Miramichi Atlantic salmo (Salmo salar) parr. Can. J. Fish. Aquat. Sci. 59:1553-1562.

Lyons J, Zorn T, Stewart J, Seelbach P, Wehrly K, Wang L, 2009. Defining and characterizing coolwater streams and their fish assemblages in Michigan and Wisconsin, USA. N. Am. J. Fish. Manage. 29:1130-1151.

Magnuson JJ, Webster KE, Assel RA, Bowser CJ, Dillon PJ, Eaton JG, Evans HE, Fee EJ, Hall RI, Mortsch LR, Schindler DW, Quinn FH, 1997. Potential effects of climate changes on aquatic systems: Laurentian Great Lakes and Precambrian Shield Region. Hydrol. Process. 11: 825-871.

Mantua N, Hare S, Zhang Y, Wallace JM, Francis R, 1997. A Pacific interdecadal climate oscillation with impacts on salmon production. Bull. Am. Meteorol. Soc. 78:1069-1079.

Marine KR, Cech JJ, 2004. Effects of high water temperature on growth, smoltification, and predator avoidance in juvenile Sacramento River Chinook Salmon. N. Am. J. Fish. Manage. 24:198-210.

Matthews KR, 2010. California golden trout and climate change: is their stream habitat vulnerable to climate warming?, p. 81-87. In: R.F. Carline and C. LoSapio (eds.), Conserving wild trout. Proceedings of the Wild Trout X symposium, Bozeman.

Matthews KR, Berg NH, 1997. Rainbow trout responses to water temperature and dissolved oxygen stress in two southern California stream pools. J. Fish Biol. 50:50-67.

Mesa MG, Weiland LK, Wagner P, 2002. Effects of acute thermal stress on the survival, predator avoidance, and physiology of juvenile fall Chinook salmon. Northw. Sci. 76:118-128.

Morgan PE, Heyerdahl K, Gibson CE, 2008. Multiseason climate synchronized widespread forest fires throughout the 20th century, Northern Rockies, USA. Ecology 89:717-728.

Morrison J, Quick MC, Foreman MGC, 2002. Climate change in the Fraser River watershed: flow and temperature projections. J. Hydrol. 263: 230-244.

Mote PW, Hamlet AF, Clark MP, Lettenmaier DP, 2005. Declining mountain snowpack in western North America. Bull. Am. Meteorol. Soc. 86:39-49.

Mote PW, Parson EA, Hamlet AF, Keeton WS, Lettenmaier D, Mantua N, Miles EL, Peterson DW, Peterson DL, Slaughter R, Snover AK, 2003. Preparing for climatic change: The water, salmon, and forests of the Pacific Northwest. Climatic Change 61:45-88.

Nakano S, Kitano F, Maekawa K, 1996. Potential fragmentation and loss of thermal habitats for charrs in the Japanese archipelago due to climatic warming. Freshwater Biol. 36:711722 .
Nakicenovic N, Alcamo J, Davis G, de Vries B, Fenham J, Gaffin S, Gregory K, Grubler A, Jung TY, Kram T, 2000. Special report on emissions scenarios. Working Group III, Intergovernmental Panel on Climate Change (IPCC). Cambridge University Press, Cambridge.

Nusslé S, Matthews KR, Carlson SM, 2015. Mediating water temperature increases due to livestock and global change in high elevation meadow streams of the Golden Trout Wilderness. PLoS One 10):e0142426.

Official Mexican Standard, 2010. Environmental ProtectionMexican native species of wild flora and fauna risk categories and specifications for their inclusion, exclusion or change-list of species at risk. NOM-059-SEMARNAT-2010. Mexico, Official Mexican Standard.

Parmesan C, Yohe G, 2003. A globally coherent fingerprint of climate change impacts across natural systems. Nature 421:37-42.

Petersen JH, Kitchell JF, 2001. Climate regimes and water temperature changes in the Columbia River: bioenergetic implications for predators of juvenile salmon. Can. J. Fish. Aquat. Sci. 58:1831-1841.

Pope VD, Gallani ML, Rowntree PR, Stratton RA, 2000. The impact of new physical parametrizations in the Hadley Centre climate model: HadAM3. Climate Dynam. 16:123-146.

Quinn TP, 2005. The behavior and ecology of Pacific salmon and trout. University of Washington Press, Seattle.

Rahel FJ, 2002. Using current biogeographic limits to predict fish distributions following climate change. Am. Fish. Soc. Symp. 32:99-110.

Reeves GH, Everest FH, Hall JD, 1987. Interactions between the redside shiner (Richardsonius balteatus) and the steelhead trout (Salmo gairdneri) in western Oregon: the influence of water temperature. Can. J. Fish. Aquat. Sci. 44:1602-1613.

Reyes-Coca S, García-López JJ, 1991. Climatología de Baja California: Sierra de San Pedro Mártir, p. 29-33. In C. Lazcano (ed.), Memories of the III Week of Exploration and History: Sierra de San Pedro Mártir. Universidad Autónoma de Baja California, Ensenada.

Rieman BE, Isaak DJ, 2010. Climate change, aquatic ecosystems, and fishes in the Rocky Mountain West: implications and alternatives for management. Gen. Tech. Rep. RMRSGTR-250. Fort Collins, CO: U.S. Department of Agriculture, Forest Service, Rocky Mountain Research Station.

Rieman BE, Isaak DJ, Adams S, Horan D, Nagel D, Luce C, Myers D, 2007. Anticipated climate warming effects on bull trout habitats and populations across the Interior Columbia River Basin. T. Am. Fish. Soc. 136:1552-1565.

Root TL, Price JT, Hall KR, Schneider SH, Rosenzweig C, Pounds JA, 2003. Fingerprints of global warming on wild animals and plants. Nature 421:57-60.

Ruiz-Campos G, 2017. [La trucha arcoíris de la Sierra San Pedro Mártir: bionomía, ecología poblacional, hábitat y conservación].[Book in Spanish]. Tirant Lo Blanch, Ciudad de México.

Ruiz-Campos G, Pister EP, 1995. Distribution, habitat, and current status of the San Pedro Mártir trout, Oncorhynchus mykiss nelsoni (Evermann, 1908). Bull. South Calif. Acad. Sci. 94:131-148.

Ruiz-Campos G, Camarena-Rosales F, González-Acosta AF, 
Maeda-Martínez AM, García-De León FJ, Varela-Romero A, Andreu-Soler A, 2014. [Estatus actual de conservación de seis especies de peces dulceacuícolas de la península de Baja California, México].[Article in Spanish]. Rev. Mex. Biodivers. 85:1235-1248.

Sokal RR, Rohlf FJ, 1981. Biometry. W. H. Freeman \& Co., San Francisco. 219 pp.

Stocker TF, Qin D, Plattner GK, Tignor M, Allen SK, Boschung J, et al. IPCC, 2013. Climate change 2013: the physical science basis. Contribution of Working Group I to the Fifth Assessment Report of the Intergovernmental Panel on Climate Change. 2013.
Verhille CE, English KK, Cocherell DE, Farrell AP, Fangue NA, 2016. High thermal tolerance of a rainbow trout population near its southern range limit suggests local thermal adjustment. Conserv. Physiol. 4:cow057.

Wenger SJ, Isaak DJ, Dunham JB, Fausch KD, Luce CH, Neville HM, Rieman BE, Young MK, Nagel DE, Horan DL, Chandler GL, 2011. Role of climate and invasive species in structuring trout distributions in the Interior Columbia Basin, USA. Can. J. Fish. Aquat. Sci. 68:988-1008.

Westerling AL, Hidalgo HG, Cayan DR, Wetnam TW, 2006. Warming and earlier spring increases western U.S. forest wildfire activity. Science 313:940-943. 